Folia Forestalia Polonica, series A - Forestry, 2017, Vol. 59 (2), 159-162

SHORT COMMUNICAHON

DOI: $10.1515 / \mathrm{ffp}-2017-0016$

\title{
Emerging forest disease in Europe and North America
}

\author{
Tomasz Oszako ${ }^{1}$, Jacek Olchowik ${ }^{2}$, Adam Szaniawski², Stanisław Drozdowski ${ }^{3}$, \\ Marta Aleksandrowicz-Trzcińska ${ }^{2}$ \\ ${ }^{1}$ Bialystok University of Technology, Faculty of Forestry in Hajnówka, Piłsudskiego 8, 17-200 Hajnówka, Poland, \\ e-mail: T.Oszako@ibles.waw.pl \\ ${ }^{2}$ Warsaw University of Life Sciences - SGGW, Faculty of Forestry, Department of Forest Protection and Ecology, \\ Nowoursynowska 159, 02-776 Warsaw, Poland \\ ${ }^{3}$ Warsaw University of Life Sciences - SGGW, Faculty of Forestry, Department of Silviculture, Nowoursynowska 159, \\ 02-776 Warsaw, Poland
}

Globalization and increase of International Trade (larger cargo and faster ships) cause more and more problems in contemporary plant protection in agriculture, horticulture and forestry sectors. The elaborated EU quarantine rules, sufficient in the past, have stopped working in the new circumstances. It is especially frustrating to foresters whose forests are in danger. The main pathway is the soil attached to plant roots of seedlings and asymptomatic plants for plantings. Some other wood goods like wood fire also need regulation. There is hope that the quickly developing molecular tools allow to detect and identify species in environmental samples (soil, water and plant tissue) on time (Nevoigt et al. 2010; Nowakowska et al. 2016). The pathway oriented legislation seems to be the most efficient way to mitigate this situation. The new IUFRO group "7.03.12 - ALIEN INVASIVE SPECIES AND INTERNATIONAL TRADE was created to deal with this topic. There are many examples of severe losses in Europe and North America due to the emerging diseases like ash dieback caused by the alien fungus Hymenoscyphus fraxineus and Agrillus plannipenis, Sudden Oak Death and Japanese larch - Phytophthora ramorum, alder decline - P. alni, European oak decline phenomenon - complex disease with significant contribution of phytophthoras, mainly P. quercina. Interactions between health status and genetic variability were often sought by scientists (Nowakowska and
Oszako 2008). It seems that research on resistance/ tolerance of forest tree species to these new threats are urgently needed.

An international IUFRO conference: Working Party 7.02.02 'Invasive Forest Pathogens \& Implication for Biology \& Policy' was held in Niagara Falls (Canada) from 6 to 13 May 2017. The meeting was attended by 46 scientists from numerous word wide research centres (Europe, Asia, North and South America). The purpose of the meeting was to provide an international knowledge on the spread of invasive species of pathogens and insects in forest ecosystems. The conference consisted of several sessions, including invasive forest pathogens, Pitch cancer and advances in pathogen detection, Botryosphaeriaceous and other forest pathogens like Hymenoscyphus fraxineus, conifer foliar diseases and stem diseases. The Polish delegation from IBL and SGGW presented several oral and poster presentations:

- Oak decline phenomenon in Poland, relationships between genetic structure and healthiness.

- Interaction between Hymenoscyphus fraxineus and Phytophthora species in common pathogenicity test on young ash (Fraxinus excelsior) seedlings.

- The impact of effective microorganism and organic fertilizers on the growth and mycorrhizal colonization of Fagus sylvatica and Quercus robur seedlings in bare-root nursery experiment. 
- Molecular assessment of the latent endophytic pathogen Gnomoniopsis smithogilvyi in chestnuts, rootstocks and grafts of six varieties of chestnut trees.

- Molecular diagnostics of the chestnut canker Gnomoniopsis smithogilvyi and Cryphonectria parasiti$c a$ in different tissues of Castanea sativa.

- Pseudomonas putida and Trichoderma harzianum may efficiently control the agent of chestnut brown rot and chestnut canker Gnomoniopsis smithogilvyi.

- Assessment of necrosis caused by Phytophthora plurivora on birch seedlings totally or partially defoliated.

The main topics discussed dealt with coniferous diseases, for example, the method of pine protection (Pinus strobus and $P$. resinosa) against butt and root rot Heterobasidion irregulare with the biopreparation named Rotstop C, prepared on the basis of lyophilized spores of the non-pathogenic fungus Phlebiopsis gigantea.

Other topics concerned the damage to pine needles caused by Dothistroma septosporum, and shoots by Diplodia sapinea. D. septosporum (the anamorph of Scirrhia pini, the latter renamed to Mycosphaerella pini) and Dothistroma pini (teleomorph unknown), both cause Dothistroma needle blight. Several pathways are identified so far: host plants intended for planting/grafting (excluding fruit and seeds), natural means (wind, rain, wind-driven rain, etc.), and host plants and plant parts with foliage not intended for planting (e.g., fresh branches, cut Christmas trees, etc.). The current concerns include loss of wood volume, tree mortality, and losses in terms of landscape value, amenity value, recreational uses and tourism (EFSA 2013). This research topic was coordinated by the FPS COST Action FP1102 DIAROD 'Determining Invasiveness And Risk Of Dothistroma'. Although the disease has been a problem in the southern hemisphere for many years, only recently has it caused significant damage to plantations and natural forest ecosystems in Europe. The biosecurity implications relating to this recent upsurge are unclear, and this has raised a number of important questions: Are these fungi recently introduced, or is it that they are changing in behaviour, possibly due to changing climatic conditions? Alternatively, is the dramatic increase in disease intensity and geographical and host range due to the introduction of more aggressive strains? Is this situation likely to worsen, or maybe improve under future management and climate change scenarios? What are the most suitable management strategies? This Action, DIAROD, built on the foundations of the International Dothistroma Alliance (IDA), established in 2006 to help combat the new problems faced due to this disease. The DIAROD cost Action synthesized knowledge, encouraged collaborative research to address the key questions, determined future research priorities, and used the resulting information to develop management strategies applicable to this evolving disease and other future disease threats.

Also, the main problem of forest protection in deciduous forests in North America is the damage of ash trees caused by Agrilus plannipenis, this insect species is a potential threat to European ash stands too because the insect species is already present in the European part of Russia. So far, in Europe, the ash dieback is mainly caused by the fungus not yet present in North America - Hymenoscyphus fraxineus (anamorph Chalara fraxin$e a$ ); currently, research is underway on seeking methods to mitigate losses in forestry. Apart from this, trials on tree resistance against $H$. fraxineus against some viruses are being tested that could reduce the virulence of this pathogen. Also, FPS COST Action FP1103 "Fraxinus dieback in Europe: elaborating guidelines and strategies for sustainable management (FRAXBACK)" dealt with the severe dieback of Fraxinus spp., which has been observed in most European countries. This emerging disease resulted in massive tree mortality, threatening the existence of Fraxinus over the continent. Alien and invasive fungus, probably originated in Japan, was a subject of many European national research programs, focusing on numerous aspects of the biology and ecology of the disease. The FRAXBACK shared and synthesised the available knowledge, generated comprehensive understanding of Fraxinus dieback phenomenon and elaborated practical guidelines for sustainable management of ash stands in Europe. The Action implemented innovative interdisciplinary approach, and included forest pathologists, tree breeders and silviculturists. It delivered: guidelines for sustainable management of Fraxinus in Europe; the European database for diebackresistant Fraxinus genotypes/families/populations and established/planned progeny trials; elaborated illustrated brochures on Fraxinus dieback; disease distribution maps; website; book and special issue of Baltic Forestry https://www.slu.se/globalassets/ew/org/inst/mykopat/ forskning/stenlid/advances-in-ash-dieback-research. 
pdf and https://www.balticforestry.mi.lt/bf/downloads/ BF_2017_1_Internet.zip.

Plane-tree (Platanus) disease in Europe is spreading due to infection by the fungus Ceratocystis platani, which is steadily spreading in the southern Europe. The main pathway is related to human activity such as pruning of trees with contaminated tools (machineries). Natural spread via water courses, root anastomosis, insects, contaminated insect frass and sawdust was also observed. C. platani is a highly infective pathogen with the potential to cause great impact, but which currently has limited distribution in the three EU Member States, that is, Italy, France and Greece. Following the pest categorisation carried out by EFSA PLH Panel in 2014 (EFSA 2014), in which it was proposed to list the pathogen as a Union Quarantine pest, the EC asked for a full pest risk assessment with the aim to develop RROs on the basis of the mechanisms of spread (Jeger et al. 2016). Hosts, particularly the most susceptible ones, are widely grown in most of the MSs and the eco-climatic conditions are suitable for the establishment of pathogen in non-infested areas. The pest is strongly associated with plants for planting, which can spread the pathogen into new areas or MS. The pest can be eradicated when the infection does not occur close to water.

In Canada, the beech trees are damaged by the syndrome of scale Cryptococcus fagisuga and fungi of the genus Neonectria. The disease results when the beech scale insect, attacks the bark, creating a wound. Later, two different fungi Neonectria faginata (previously Nectria coccinea var. faginata) and Neonectria ditissima (previously Nectria galligena) common to North America can invade the tree through the wound, causing a canker to form. In subsequent years, new cankers will continue to form, ultimately leading to the death of the tree. In Europe, $N$. coccinea is the primary fungus causing the infection (Sinclair et al. 2005). The infection in European trees occurs in the same manner as it does in the North American trees. Though the disease still appears in Europe, it is less serious today than it was in the past (Tainter et al. 1996). Beech bark disease was first documented in Europe in 1849. At first, it was believed that the scale insect was the main cause of the disease. It wasn't until 1914 that the Neonectria fungus was associated with the disease (Houston et al. 1983). The first outbreak of beech bark disease in North America appeared in the American beech (Fagus grandifolia) in Nova Scotia around 1920. The disease then started to spread to the south and west. The first case of beech bark disease in the United States was reported in 1929 in Massachusetts. By 2004, the disease had spread as far west as Michigan and as far south as western North Carolina (Tainter et al. 1996; Sinclair et al. 2005).

During the field trip, the participants learned about conservation issues in Ontario's natural parks: Niagara Glen Nature Centre (Butternut site, Figure 1), Ball's Falls Conservation Area (beech bark disease site) and

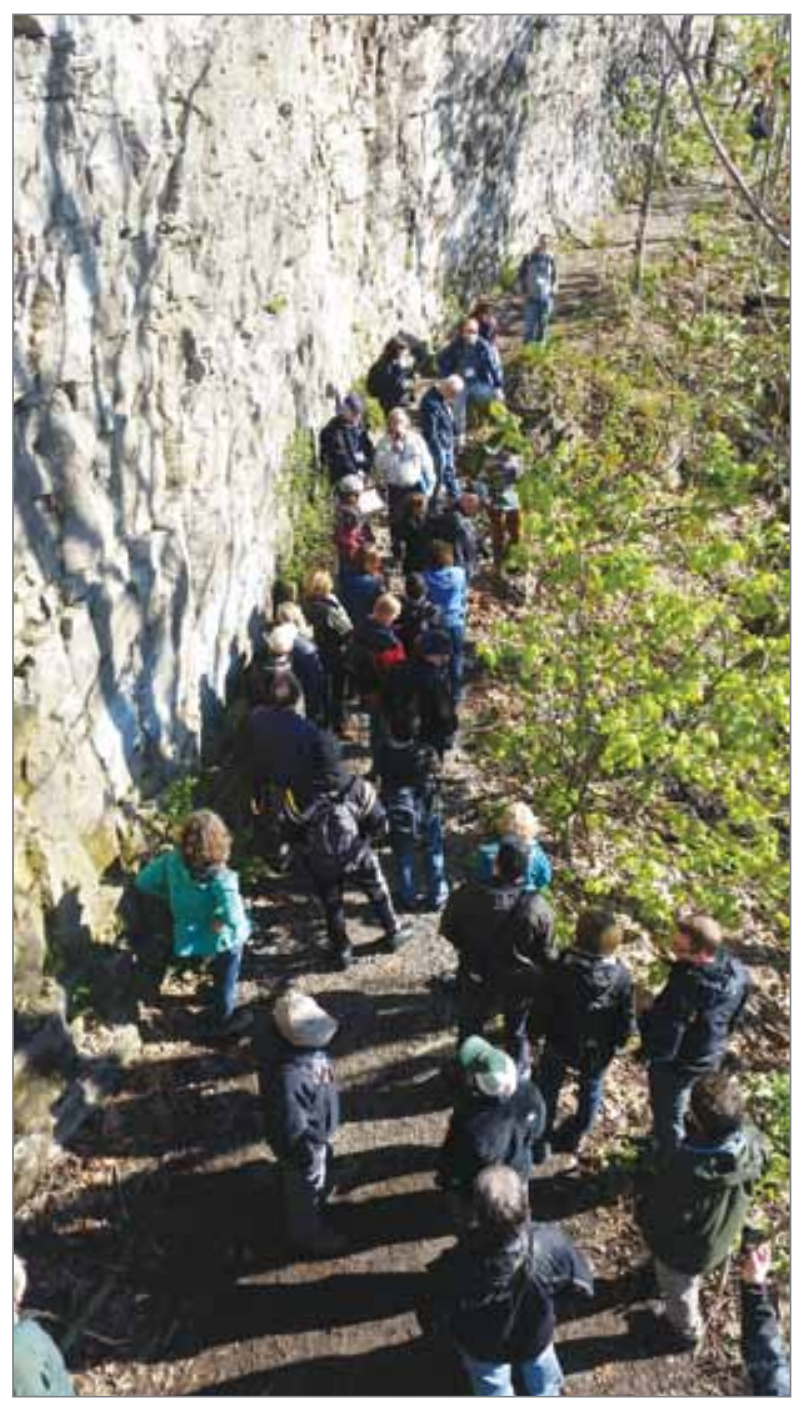

Figure 1. Participants of the conference had a chance to see butternut canker, an ecologically and economically important disease in North America, caused by an exotic fungal pathogen Ophiognomonia clavigignetijuglandacearum 
visited the Simcoe Research Station (hazelnut research and disease plot) and Norfolk County Woodlot (Heterobasidion root disease site).

The next meeting of the IUFRO section 07.02 .02 is scheduled for 2019 in Florence, Italy.

\section{References}

Bergdahl A.D., Hill A. 2016. Diseases of trees in the Great Plains. General Technical Report, RMRSGTR-335, 1-229.

EFSA Panel on Plant Health (PLH). 2013. Scientific Opinion on the risk to plant health posed by $D o$ thistroma septosporum (Dorog.) M. Morelet (Mycosphaerella pini E. Rostrup, syn. Scirrhia pini) and Dothistroma pini Hulbary to the EU territory with the identification and evaluation of risk reduction options. EFSA Journal, 11 (1), 3026. DOI: 10.2903/j.efsa.2013.3026.

EFSA Panel on Plant Health (PLH). 2014. Scientific Opinion on the pest categorisation of Ceratocystis platani (Walter) Engelbrecht et Harrington. EFSA Journal, 12 (10), 3858. DOI: 10.2903/j. efsa.2014.3858.

Houston D.R., O’Brien J.T. 1983. Beech Bark Disease. Forest Insect and Disease Leaflet, 75: 1-7.
Jeger M., Bragard C., Chatzivassiliou E., DehnenSchmutz K., Gilioli G., Jaques Miret J.A., MacLeod A., Navajas Navarro M., Niere B., Parnell S., Potting R., Rafoss T., Urek G., Van Bruggen A., Van der Werf W., West J., Winter S., Santini A, Tsopelas P., Vloutoglou I., Pautasso M., Rossi V. 2016. Scientific opinion on the risk assessment and reduction options for Ceratocystis platani in the EU. EFSA Panel on Plant Health(PLH). EFSA Journal, 14 (12), 4640. DOI: 10.2903/j.ef s a.2016.

Nevoigt F., Oszako T., Nowakowska J.A. 2010. Monitorowanie chorób wywołanych przez patogeniczne lęgniowce za pomocą analiz DNA. Sylwan, 154 (7), $450-455$.

Nowakowska J.A., Malewski T., Tereba A., Oszako T. 2016. Rapid diagnosis of pathogenic Phytophthora species in soil by real-time PCR. Forest Pathology, 21 (1), 1-4. DOI: http://dx.doi.org/10.1111/ efp.12303.

Nowakowska J.A., Oszako T. 2008. Stan zdrowotny i zróżnicowanie genetyczne buka zwyczajnego w Nadleśnictwie Siewierz na podstawie analiz chloroplastowego DNA. Sylwan, 9, 11-20.

Sinclair W.A., Lyon H.H. 2005. Diseases of trees and shrubs. 2nd ed. Cornell University Press, Ithaca, NY.

Tainter F.H., Baker F.A. 1996. Principles of forest pathology. John Wiley \& Sons, Inc., New York, NY. 